\title{
LENGYEL ÉS MAGYAR VEZETŐ TESTÜLETEK A FELSŐOKTATÁSBAN
}

\author{
RÓNAY ZOLTÁN ${ }^{a, *}$ - DOMINIK ANTONOWICZ ${ }^{\mathrm{b}}$ - MARTA JAWORSKA \\ ${ }^{a}$ ELTE Pedagógiai és Pszichológiai Kar, Neveléstudományi Intézet \\ ${ }^{b}$ Department of Higher Education and Research Studies, \\ Nicolaus Copernicus University in Toruń (Lengyelország)
}

A tanulmány két viszonylag új felsőoktatási reformot vizsgál Lengyelországban és Magyarországon. Mindkettő egyfajta board (felügyelő testület) bevezetésére irányult különböző elnevezéssel. Az összehasonlító tanulmány alapja a két ország közös (kommunista) múltja, földrajzi helyzete (kelet-közép-európai térség) és a humboldti egyetemi modell öröksége. Az elemzés a reformok előzményeinek bemutatása után magát a két nemzeti reformot vizsgálja, megvilágítva a különbségeket és hasonlóságokat a lengyel egyetemi tanács és a magyar konzisztórium felépítése, hatásköre és felelössége, valamint az egyetemi autonómiához való viszonya tekintetében. Ezzel is hozzá kíván járulni a boardizmusról jelenleg folyó szakmai diskurzushoz, értékelvén annak bevezetését e két (hasonló) nemzeti felsőoktatásban.

Kulcsszavak: boardizmus, testületek, egyetemi tanács, konzisztórium, autonómia, menedzsment

This study investigates relatively new reforms of HE in Poland and Hungary, which introduced university supervisory bodies (although under different local labels). The comparative studies between these two countries are particularly relevant due to the common (communist) past, geographical location (CEE) and Humboldtian universities. After presenting the antecedents in both countries, the analysis investigates these two national reforms shedding light on differences and similarities in respect to the structure of supervisory boards, their organizational power and responsibility, and the impact of university autonomy. By doing so, it wants to contribute to an ongoing discussion about boardism and examine how it was introduced into these two (similar) national contexts.

Keywords: boardism, boards, university councils, consistory, autonomy, management

\footnotetext{
* Levelező szerző: Rónay Zoltán, ELTE Pedagógiai és Pszichológiai Kar, Neveléstudományi Intézet, 1073 Budapest, Kazinczy u.23-27. E-mail: ronay.zoltan@ppk.elte.hu
} 
$\mathrm{A}$ szakirodalom már jó ideje foglalkozik a külső szakértők, érdekérvényesítők megjelenésével, részvételével a felsőoktatási intézmények döntéshozatalában és ellenőrzésében. Amikor a vállalkozó egyetem fogalma az ezredforduló táján a közbeszédbe jött, a felsőoktatási intézmények vezetésében a professzionalizmus, vagy inkább annak hiánya is előtérbe került (Clark 1998). Később újabb és újabb írások születtek az akadémiai szféra vezetői készségeit elemezve - felvetve az akadémikus rektor és a menedzsment problematikáját (De Groof-Švec-Neave G. 1998; Barakonyi 2004a; Hrubos 2006; Fried 2006). Ebben a kontextusban az intézményvezetés külső résztvevője a professzionalizmust jelenítette meg az egyetemek vezetésében. Ezzel egyidejüleg persze az is felmerült, hogy miként lehet biztosítani az egyensúlyt az akadémiai és a professzionális menedzsment között, miként viszonyul a hagyományos önigazgatáson alapuló autonóm müködéshez a külső beavatkozás lehetősége (Thomas 2002; Vilalta 2003; Barakonyi 2004a; Polónyi 2009). Az intézményi autonómia ismét a gondolkodás homlokterébe került, elemezve annak számos eltérő interpretációját, az akadémiai szabadsághoz való viszonyát, az esetleges összekeveredésükből következő téves következtetéseket (Setényi 1994; Bergan 2002; Hrubos 2006).

Egyes szerzők a vezetés professzionalizmusának biztosítékaként kifejezetten a boardok szerepét hangsúlyozzák. Hegedüs és Polónyi (2015) arra hívják fel a figyelmet, hogy az európai felsőoktatásban nem is nagyon akad példa olyan megoldásra, amikor a külső professzionalizmust ne testület (ti. board) biztosítaná. Az elmúlt 15-20 évben azonban sok minden jelentősen megváltozott, a professzionalizmus mellett újabb tényezők is megjelentek, amelyek az intézményvezetés hatékonyságát fokozni képesek. Amikor Veiga és munkatársai érzékelték az intézmények és azok társadalmi-gazdasági környezete közötti távolság növekedését, azt is felismerték, hogy fontosabb, hogy az intézményvezetés az intézményi partnerek, így különösen a munkaerőpiac igényeire reflektáljon, semmint az egyébként is gyakran és nem ritkán szeszélyesen változó kormányzati akaratnak próbáljon megfelelni. Ebben a megközelítésben a külső szereplők részvétele kevésbé a professzionalizmus hiányának enyhítését, sokkal inkább a stakeholderek befolyásának biztosítását szolgálja. Veiga és munkatársai boardizmus ${ }^{1}$ teóriájukban a testületek szerepét új perspektívából vizsgálták: ebben a felsőoktatási intézmények és a társadalmi-gazdasági környezet közötti interakciókat, a közös stratégiai gondolkodást és a folyamatos - külső - visszajelzés iránti igényt hangsúlyozzák. Ezért a board szorosan kötődik a külső stakeholderekhez (pl. megrendelők, munkaerőpiaci szereplők), és alkalmat ad arra, hogy az intézmény bevonja őket a stratégiai döntéshozatalba, amelyben ezáltal megjelenhetnek a társadalmi-gazdasági környezet igényei is (Veiga-MagalhãesAmaral 2015).

Ez utóbbi megjelenése egyaránt tetten érhető Lengyelországban és Magyarországon is, utóbbi esetében azonban a boardizmus gyakorlati megvalósulásáról egyáltalán nem beszélhetünk még. A konzisztórium a gyakorlatban ugyanis sokkal inkább a kormányzati érdekek megjelenítését szolgálja, nem a társadalmi-gazdasági környezet igényeire

Az eredeti kifejezésnek - boardism - még nincs elfogadott magyar fordítása, és olyan kifejezést sem találtunk, amely pontosan visszaadná a jelentését, ezért ezt a (talán) kevésbé szerencsés nyelvi megoldást választottuk. 
reflektál. Ezzel szemben a lengyel „Rada Uczelni”, ${ }^{2}$ azaz az egyetemi tanács bevezetésekor kifejezetten ez a cél vezértelte a kormányzatot, felismervén, hogy a lengyel felsőoktatási intézmények elzárkózóak, mondhatni elszigeteltek a külső partnereiktől. Így e kötelezően létrehozandó testületekkel kínáltak a problémára megoldást, egyidejűleg az intézményi autonómia növelését is szolgálva, lévén hogy a külső partnerek bevonása a kormányzattól való távolságot növeli, a függetlenséget erősíti (vö. boardizmus).

Bár az alapok azonosak, és számtalan hasonlóságot is találhatunk a két nemzeti megoldás között, mind a bevezetés oka, mind pedig a várt eredmények lényegesen különböznek a konzisztórium és a lengyel egyetemi tanács esetében. A közös az, hogy mindkét fajta testület bevezetésére egy posztkommunista, posztszocialista államban került sor egy neokonzervatív (vagy azt is mondhatjuk illiberális / az új autokráciát képviselő) kormányzat által. Ugyanakkor a lengyel megoldás elkerülendő az autonómia megsértésének lehetőségét, teljesen az intézményekre bízza a tagok kiválasztását és - talán már túlzottan is - gyenge hatáskört enged a testületnek. A magyar modell viszont minimalizálja az intézményi beleszólást, a konzisztórium hatásköre pedig kifejezetten autonómiacsökkentő funkciót tölt be (Rónay 2018, 2020). Mindazonáltal mindkét országban - az akadémiai szférában legalábbis - az autonómia konzervatív értelmezését érhetjük tetten: a céloktól függetlenül ellenzik ezen testületek létét.

\section{A boardok bevezetésének elözményei a magyar és lengyel felsőoktatásban}

Míg a modern felsőoktatási rendszerekben már az ezredfordulót megelőzően felismerték az intézményvezetés átalakításának, a szerkezet és a tevékenység professzionalizálásának szükségességét, a kommunista rezsimek összeomlása után a keleti blokk legtöbb országában egy jóval korábbi modellhez tértek vissza. A humboldti egyetem ideája ugyanis az autonómiát és önkormányzatiságot hangsúlyozza (Dobbins-Knill 2009). Márpedig ezek garantálják azt az akadémiai szabadságot, amelyben a kommunista állampárt által irányított, ellenőrzött intézményekben aligha lehetett szó. Ilyen körülmények között az akadémiai szféra ezekben az országokban magától értetődően próbálta minél jobban növelni az államtól való távolságot és függetlenséget. Egyes szerzők azonban hamar jelezték a humboldti modell eredeti formájának túlhaladott mivoltát, ráirányítva a figyelmet a modern felsőoktatásokban jelen lévő trendekre - elsősorban a professzionalizálódó egyetemi menedzsmentre (Setényi 1994; Keczer 2007). Ezen jelzéseket azonban elnyomta az újonnan megszerzett szabadsághoz való ragaszkodás. Mindeközben Magyarországon az ágazati és intézményi szinten is anyagi válsággal és lepusztult infrastruktúrával küzdő felsőoktatásban a tervgazdálkodás érájában szocializálódott intézményvezetők nem rendelkeztek a piacgazdasági körülmények közötti kormányzáshoz szükséges tapasztalattal és készségekkel sem. A kilencvenes években a magyar kormány - elkerülendő az egyes intézmények egymás utáni csődjét - a központi ellenőrzést fokozta, az állami beavatkozás mind újabb eszközeit bevezetve ahelyett, hogy az intézményvezetési szerkezet olyan átalakítására tett volna javaslatot, amely nyugati mintára kombinálja a

\footnotetext{
2 A lengyel törvényben szereplő „Rada Uczelni” kifejezés szó szerinti fordítása: egyetemi tanács. Noha a magyar hagyományok szerint az egyetemi tanács a szenátus jogelődjeként működő testületet jelenti, a továbbiakban egyetemi tanács alatt lengyel kontextusban nem a legfőbb döntéshozó szervet, hanem az újonnan bevezetett tanácsadó jellegű testületet (boardot) értjük.
} 
professzionalizmust az autonómia magas szintjével. Ebben az időszakban feltehetően ezért a szakirodalom még mindig a professzionalizmus hiányát hangsúlyozta és nem a társadalmi-gazdasági környezettel való kapcsolat szükségességét (Hrubos-SzentannaiVeroszta 2003; Barakonyi 2004a; Polónyi 2006).

Talán ezért is tünik meglepőnek, hogy a magyar kormány épp 2000-ben terjesztett elő egy olyan törvénymódosító javaslatot, amelyet elfogadva az országgyülés bevezette a társadalmi tanácsok intézményét a felsőoktatásban. ${ }^{3}$ Ennek a lényege az volt, hogy minden állami támogatásban részesülő intézmény köteles volt a társadalmi-gazdasági szféra képviselőiből és külső szakemberekből egy tanácsadó testületet létrehozni a társadalmi-gazdasági igények kielégítésére irányuló intézményi tevékenység figyelemmel kísérésére, értékelésére, a képzés és képzésfejlesztés, a fejlesztési tervek véleményezésére és az intézmény oktató és tudományos munkájával, fejlesztési tervével kapcsolatos javaslatok kidolgozására. A társadalmi tanács létrehozása általános - a fenntartó személyétől független - kötelezettség volt, azonban az állami támogatásban nem részesülő, valamint a kizárólag hitélettel összefüggő képzést végző intézményekben a fenntartó egyetértésével volt lehetőség ettől eltérni. A törvénymódosítás részletes indokolása szerint mindez az egyetemek és főiskolák szakmai-intellektuális társadalmi támogatásának megerősítését szolgálta, mert összetételüknél fogva ezek a testületek voltak a leginkább alkalmasak arra, hogy az intézmények képzésfejlesztésében a társadalmi, gazdasági, munkaerőpiaci szempontokat érvényesítsék. Ezért biztosított számukra a törvény meghatározott oktatási és tudományos feladatokban véleményezési jogosultságot. ${ }^{4} \mathrm{~A}$ társadalmi tanácsok működéséről sajnos kevés publikus információ áll rendelkezésre, és kutatásukra sincsen adat, így sem visszajelzésről, sem a velük kapcsolatos tapasztalatokról nem tudunk beszámolni. Mindazonáltal a 2005-ös felsőoktatási törvény már nem rendelkezett ezen testületről.

A magyar kormányzat az uniós csatlakozással egyidejűleg tért vissza boardok bevezetésének témaköréhez (lásd a $\mathrm{CSEFT}^{5}$ vitaanyagok különböző variánsait). A később irányító testületként ismertté vált új jogintézmény szükségességét kizárólag a professzionalizálódás iránti igénnyel magyarázták, a társadalmi-gazdasági környezettel való kapcsolat már fel sem merült. Az irányító testület mindenesetre egy új modell volt, amelynek a fenntartói jogosítványai egy részét adta volna át a kormányzat. Ez a logika kétségtelenül a professzionalizmust az autonómianöveléssel kombináló megoldásokra emlékeztet, azonban a tagok kiválasztásban a kormányzat jelenléte (tagok - igaz kisebbségének - delegálása) épp az ellenkezoojét láttatta. Az akadémiai szféra ugyanis az autonómia elleni durva támadásként értékelve a tervet mindent megmozgatott annak meghiúsításáért.

A minden korábbinál erőteljesebb ellenállás sikeresnek bizonyult: a köztársasági elnök kezdeményezésére az Alkotmánybíróság megsemmisítette a törvény ezen rendelke-

L. a felsőoktatásról szóló 1993. évi LXXX. törvény és a közoktatásról szóló 1993. évi LXXIX. törvény módosításáról szóló 2000, évi XCVII. törvényt.

4 Lásd a Magyar Köztársaság Kormánya T/2524. számú törvényjavaslatát a felsőoktatásról szóló 1993. évi LXXX. törvény és a közoktatásról szóló 1993. évi LXXIX. törvény módosításáról, 14. o.

5 Csatlakozás az európai felsőoktatási térséghez (CSEFT) című program, amelyet 2002-ben indított el az Oktatási Minisztérium a bolognai rendszer bevezetésének, illetve egy új felsőoktatási törvény előkészítésének érdekében. A CSEFT már mint Magyar Universitas Program vált hivatalossá [lásd: 1068/2004. (VII. 9.) számú Korm. határozat]. 
zéseit (Barakonyi 2009; Szolár 2010). Ezzel elfogadta az akadémiai szféra többségének(?) véleményén alapuló államfői érvelést, miszerint - szemben a kormányzat autonómiát növelő beavatkozásként értékelő álláspontjával - ez egy, az intézmény szervezetén kívül álló és a napi müködésre is külső (hovatovább kormányzati) befolyást gyakorló testület, ezért sérti az autonómiához való alkotmányos jogot.

Ezt követően az országgyúlés a gazdasági tanácsokat hozta létre, amelybe a tagok egy (kisebb) részét még mindig a kormány delegálhatta, hatásköre azonban sokkal gyengébb volt, mint ahogy a professzionalizmus biztosításában játszott lehetséges szerepe is. Bár első látásra az akadémiai szféra ellenállása sikeresnek tűnhet, de még a gazdasági tanácsok megítélése is ellentmondásos: az intézményvezetők többsége szintén az autonómia korlátozásaként értékelte, de legalábbis haszontalannak tartotta, s csak a kisebbség szerint váltották be a hozzájuk füzött reményeket (Polónyi 2006; Keczer 2008). A szakirodalom az irányító testületek megakadályozását sem tekinti sikertörténetnek, sokkal inkább a magyar egyetemi menedzsment struktúra modern felsőoktatási rendszerektől való távolodásaként értékeli (Szolár 2010; Keczer 2016). Eközben a társadalmi-gazdasági környezettel való kapcsolat kérdésköre a - legalábbis politikai - közbeszédből hosszabb időre ismét kikerült.

A szervezeti átalakítás, korszerűsítés Lengyelországban sem volt sikeresebb. Az 1990-es felsőoktatási törvényt annak ellenére is számos nyilvános kritika illette, hogy széles körü autonómiát biztosított az egyetemeknek minden lehetséges tárgykörben. Popłonkowski (1996) szerint ezek a kritikák elsősorban az egyetem hagyományos, mondhatni idealista módon kialakított autonómiája mint bármilyen külső befolyástól mentes zárt rendszer képzetéből eredtek. Persze a feltétel nélküli és teljes autonómiára vonatkozó követelések soha nem voltak teljesíthetők, hiszen a felsőoktatási intézmények Lengyelországban is közpénzekből működtek, amelyek felhasználása értelemszerüen maga után vonta a kormányzati ellenőrzés szükségességét. Mindazonáltal a lengyel felsőoktatásban továbbra is erősen tartja magát az a meggyőződés, miszerint az egyetemi működés kizárólag az akadémiai közösségre tartozik. Ezért minden olyan reformkezdeményezés teljes ellenállásba ütközött, amelynek célja az volt, hogy - lehetővé téve a külső érdekeltek bevonását - az egyetemek nyissanak a külvilág felé, mert a lengyel akadémiai közösség számos képviselője alapból utasít vissza minden olyan elképzelést, amely korlátozza az egyetemi autonómiát. Így amikor egy, a mai egyetemi tanácsnak megfelelő testület intézményének bevezetése 2007-2008 táján felmerült, e diskurzust az akadémiai szférának magyarhoz hasonló heves ellenállása gyorsan le is zárta (lásd részletesen: Dziedziczak-Foltyn 2018). Hasonlóan a magyarhoz, e testületeket a lengyel akadémiai közvélemény is feleslegesnek, az autonómiát fenyegetőnek és általában a lengyel egyetemi hagyományoktól idegennek tekintette, a kezdeményezést a politika beavatkozási kísérleteként és az intézményi autonómia csökkentéseként értékelte.

Magyarországon az egyetemi autonómiához való kormányzati viszonyulás 2010 után radikálisan megváltozott. Már a gazdasági tanácsok kormányzati delegáltjainak többnyire minisztériumi alkalmazottakkal való feltöltése előrevetítette a kormányzat intézményirányításhoz való viszonyát. Első lépésben az Alaptörvény negyedik módosításával lényegében minimálisra csökkent az autonómia, az állami intézmények esetében a közvetlen kormányzati irányítást garantálva a gazdálkodás területén. Második lépésben az intézményvezetésben megjelent a rektorral egyenrangú, de teljes egészében a kormányzathoz tartozó első számú vezető, a kancellár (Rónay 2019a, 2020). A harmadik hasonló 
lépés előtt jelent meg a „Fokozatváltás a felsőoktatásban. A teljesítményelvű felsőoktatás fejlesztésének irányvonalai” című koncepcionális dokumentum (a továbbiakban: Koncepció), amely először beszélt a konzisztóriumokról mint ami a külső érdekeltek (fenntartó, társadalom) képviseletét biztosító és az akadémiai és gazdasági stratégiai döntéseket elválasztó megoldás. Ugyan a Koncepcióban felbukkan a társadalmi-gazdasági környezet képviselőinek hangsúlyos szerepe, azonban - összességében olvasva azt és a gyakorlatot is tekintve - a boardizmus megjelenése nem érdemi, inkább csak szlogen.

\section{A lengyel egyetemi tanács és a magyar konzisztórium összehasonlító elemzése}

A fentiekből láthatóan a kormányzat a két hasonló történelmi hagyománnyal rendelkező országban hasonló körülmények között kísérletezett különféle intézménykormányzási reformokkal, amelyek - az előbb említett hasonlóság okán - közel azonos fogadtatásra találtak. A legutóbbi kísérletek is ebbe a körbe esnek, azonban a részletek szintjén már számos jelentős eltérést találunk.

\section{A bevezetés indokai}

Mindjárt a reform, azaz az adott board bevezetésének indokai térnek el jelentősen. Habár az okok között mindkét esetben megjelenik a külső partnerek, a társadalmi-gazdasági környezet felé történő nyitás szükségessége, a hangsúlyok számottevően különböznek. Míg Lengyelországban ismét megjelenik a professzionális menedzsment iránti igény, erre vonatkozó utalást a magyar Koncepcióban nem találunk. Lengyelországban a reform lényegében két rendszerszintű változást célzott: meghatározni az ún. zászlóshajó intézmények körét, valamint az egyetemi kormányzás modernizálását. Ez utóbbi keretében - visszakanyarodva az ezredforduló diskurzusához - ismét felmerült, hogy az egyre öszszetettebb szervezetekké váló egyetemek professzionális pénzügyi és menedzsment irányítást igényelnek. 2018-ra ugyanis az egyetemek már elvesztették azt a sajátosságukat, amelyet Weick (1976) egységes identitás nélküli önálló célokkal, víziókkal rendelkező, függetlenül fejlődő szervezetek (pl. karok) egyfajta laza kapcsolódásaként (szövetség) írt le. Ezért felmerült az igény a rektorok és a végrehajtásért felelős menedzsment szerepének erősítése iránt. A reform végül az ún. 2.0 törvényben ${ }^{6}$ öltött testet, amelynek eredményeképpen az egyetemek nem vesztették el autonómiájukat, sőt még erősödtek is azáltal, hogy a belső szervezeteik korábbi szabadsága csökkent. Ezzel az egyetemek valódi önkormányzattal rendelkező szervezetté váltak. Ez azért is alakulhatott így, mert a lengyel kormány következetesen elkötelezett volt és maradt az intézményi autonómia előmozdítása és az egyetemek önigazgatásának nagyobb szabadsága iránt.

Magyarországon ezzel szemben a konzisztórium bevezetésének egyik indoka az autonómia újraértelmezése volt. A Koncepció szerint ugyanis a szenátus önkormányzati módon választott, és alapvetően az egyetemen belüli érdekeltségi köröket megjelenítő, az intézmény belső „erőviszonyait” leképező testületként nem biztosítja a nem az autonómia körébe eső funkciók irányíthatóságát, a fenntartó beavatkozási-irányítási szerepét a stratégiai-gazdasági kérdésekbe, amelyhez a kancellár egyetértési joga sem elég hatékony.

Lásd: Ustawa z dnia 20 lipca 2018 r. - Prawo o szkolnictwie wyższym i nauce (Ustawa 2.0), azaz a 2018. évi 20-as törvény a felsőoktatásról és a tudományról. 
A másik indok a külső érdekeltségi kör megjelenítése volt. Ebben hasonlóság mutatkozik a lengyel reform indokolásával, ahol a másik elvárás az egyetemek vezetésének már említett „kinyitása” a külvilág felé. Számos tanulmány számolt be ugyanis arról, hogy a lengyel egyetemek elzárkóznak a külvilágtól, sőt elszigetelik magukat és csak gyengén kapcsolódnak a külső partnerekhez (World Bank/EIB 2004; Fulton et al. 2007). A modern egyetem azonban már egy szélesebb ökoszisztéma része és ez számos előnnyel jár (PSF 2017). Az egyetemi tanácsot egyfajta hídnak szánták a társadalmi-gazdasági környezet felé, megnyitva a lehetőséget arra, hogy a felőlük érkező szempontok, észrevételek becsatornázódhassanak a döntéshozatalba. A külső kapcsolat a magyar Koncepcióban is megjelent, amely ezen - szemben a szakirodalommal (vö. boardizmus) - nem csupán a társadalom (vö. társadalmi-gazdasági környezet), hanem a fenntartó (azaz az állam) igényeit is értette. A lengyel megoldástól eltérően a Koncepció - egyebek mellett a „board of trustees” mintájára - egy, „a fenntartó által felkért, nagy tekintélyü, a saját területükön elismert, az intézményért felelősséget érző szakemberek" alkotta testület létrehozását (Koncepció: 57) javasolta.

A lengyel reformnak volt egy harmadik eleme is, mégpedig az elszámoltathatóság. $\mathrm{A} z$ Európai Bizottság egy jelentése (PSF 2017) szerint a lengyel egyetemek nem rendelkeznek azzal a professzionális és hatékony vezetési struktúrával, amely nélkül a modern komplex intézmények nem irányíthatók hatékonyan, és nem használhatják ki az autonómia adta előnyöket sem, ha a struktúra nem biztosítja a külső elszámoltathatóságot. A jelentés hangsúlyozta, hogy az autonómia esetében is fontos a fékek és egyensúlyok müködtetése, amelyben mind a külső partnerek (társadalom, finanszírozók stb.), mind a belső érdekeltek (oktatók, támogató személyzet és hallgatók) részt vesznek, ezért valamennyi felsőoktatási intézményben külső stakeholderek részvételét javasolta. Ilyen elemet a konzisztórium kapcsán nem találunk. Sem a magyar Országgyülés által végül 2015-ben (a lengyel egyetemi tanácsot bevezető törvénymódosítást három évvel megelőzően) elfogadott, a konzisztóriumokat megteremtő törvénymódosítás, sem a következő évben napvilágot látó végleges felsőoktatási stratégia (Fokozatváltás a felsőoktatásban - középtávú szakpolitikai stratégia 2016 - a továbbiakban: Stratégia 2016) nem említi a felelősség kérdéskörét. Sőt, utóbbi már csak utal „a fenntartó, és a külső érdekeltségi kör (gazdaság, közösség stb.) érdekeinek megjelenítését, valamint szerepvállalását az intézmények müködésében" biztosító konzisztóriumra (Stratégia 2016: 29), amely a fenntartó által - az adott intézmény társadalmi-gazdasági környezetének releváns szereplőiből létrehozva egyetértési jogot gyakorol az önkormányzati módon választott szenátusnak az intézmény hosszú távú, stratégiai döntései kapcsán. Szemben tehát a Lengyelországban megfogalmazott elszámoltathatósági követelménnyel, a hazai konstrukció a felelősség kérdéskörét nem rendezi (Rónay 2019a), sőt lényegében kifejezetten a felelösséget elimináló rendszert hoz létre az egyetértési jog révén, ugyanis az egyszemélyi döntéshozó számára a támogató, de különösen a nem támogatott döntések esetében a testületi döntés felmentést adó hivatkozási alap, miközben a testület sem kollektíven, tagjai pedig a tisztázatlan jogállásból és külön szabályozás hiányából adódóan nem tartoznak felelösséggel döntésükért (Rónay 2020).

Látható tehát, hogy a két reformnak már az indokai is alapvetően mások, s azok mögött a kormányzati szándékok is jelentősen eltérőek voltak, nem meglepő ezek után, hogy a két board is jelentősen eltér egymástól. Az 1. táblázat mutatja be a legfőbb jellemzők összehasonlítását, amelyet a következő alfejezetekben részletesebben is elemzünk. 
- RÓNAY ZOLTÁN - DOMINIK ANTONOWICZ - MARTA JAWORSKA: LENGYEL ÉS MAGYAR VEZETŐ... — -

1. táblázat: A legfőbb jellemzők összehasonlítása

\begin{tabular}{|c|c|c|}
\hline Indikátor & Lengyel egyetemi tanács & Konzisztórium \\
\hline $\begin{array}{l}\text { Autonómiáboz } \\
\text { való viszony }\end{array}$ & $\begin{array}{l}\text { Nem sérti, nem korlátozza } \\
\text { Belső szervezet } \\
\text { Belső választás }\end{array}$ & $\begin{array}{l}\text { Autonómia az Alaptörvényben már eleve korlátozott } \\
\text { (lényegében sem a szervezetre, sem a gazdálkodásra nem } \\
\text { vonatkozik - de a kutatás és a tanitás tartalma, módsze- } \\
\text { rei, a tudományos igazság kérdései tekintetében fennáll) } \\
\text { - ez utóbbiakat is sérti az egyetértési jog az IFT \& } \\
\text { K+F+I stratégia elfogadásával közvetlenül } \\
\text { - költségvetési kérdésekben közvetve (vö. nincs } \\
\text { akadémiai, tudományos szabadság, ha pénzügyileg } \\
\text { korlátozható) }\end{array}$ \\
\hline \multirow[t]{9}{*}{ Hatáskör } & $\begin{array}{l}\text { az egyetem stratégiai tervének } \\
\text { véleményezése }\end{array}$ & $\begin{array}{l}\text { az intézmény stratégiai döntéseinek megalapozása } \\
\text { egyetértési jog az intézményfejlesztési terv, annak } \\
\text { részeként a kutatási-fejlesztési innovációs stratégia } \\
\text { elfogadásánál }\end{array}$ \\
\hline & $\begin{array}{l}\text { az alapszabály tervezetének } \\
\text { véleményezése }\end{array}$ & nincs ilyen hatáskör \\
\hline & $\begin{array}{l}\text { egyik esetben sem kötelező } \\
\text { figyelembe venni }\end{array}$ & \\
\hline & $\begin{array}{l}\text { az egyetem gazdálkodásának } \\
\text { felügyelete }\end{array}$ & a gazdálkodási tevékenység ellenőrzése \\
\hline & $\begin{array}{l}\text { - vélemény a költségvetési } \\
\text { tervezetekről } \\
\text { — a költségvetés végrehajtásáról } \\
\text { szóló jelentés jóváhagyása } \\
\text { - az ellenőrzési jelentés jóvá- } \\
\text { hagyása }\end{array}$ & $\begin{array}{l}\text { - egyetértési jog a szenátusi döntésekhez: } \\
\text { + költségvetés } \\
\text { + éves beszámoló } \\
\text { + vagyongazdálkodási terv } \\
\text { + gazdálkodó szervezet alapítása, gazdálkodó szerve- } \\
\text { zetben részesedés szerzése }\end{array}$ \\
\hline & nincs ilyen hatáskör & a gazdálkodási tevékenység szakmai támogatása \\
\hline & az egyetemi vezetés ellenőrzése & nincs ilyen hatáskör \\
\hline & $\begin{array}{l}\text { rektorjelöltek jelölése, egyetemi } \\
\text { szenátus véleményezése mellett* }\end{array}$ & nincs ilyen hatáskör \\
\hline & $\begin{array}{l}\text { az egyetemi szabályzatokban } \\
\text { meghatározott egyéb feladatok }\end{array}$ & nincs ilyen hatáskör \\
\hline \multirow[t]{3}{*}{$\begin{array}{l}\text { Összetétel, meg- } \\
\text { alakitás }\end{array}$} & $\begin{array}{l}7 \text { vagy } 9 \text { tagú (intézmény mére- } \\
\text { tétől függően) } \\
7 / 3 \text { vagy } 9 / 4 \text { tag kötelezően } \\
\text { külső } \\
\text { a fennmaradó } 3 / 4 \text { tag lehet } \\
\text { belső is** }\end{array}$ & $\begin{array}{l}5 \text { tagú (egységesen) } \\
\text { rektor és kancellár hivatalból } \\
3 \text { tagot a miniszter delegál }\end{array}$ \\
\hline & HÖK elnök hivatalból tag & HÖK elnök nem tag \\
\hline & $\begin{array}{l}\text { választás, visszahívás szenátusi } \\
\text { hatáskör - a törvény kife- } \\
\text { jezetten rögzíti, hogy sem a kor- } \\
\text { mánynak, sem a miniszternek } \\
\text { nincs hatásköre ebben }\end{array}$ & $\begin{array}{l}\text { javaslattételi joga van: } \\
\text { - a felsőoktatási intézmény gazdasági-társadalmi } \\
\text { környezete meghatározó szervezeteinek } \\
\text { - az intézménynek } \\
\text { - az intézményi HÖK-nek } \\
\text { visszahívás is fenntartói hatáskör }\end{array}$ \\
\hline
\end{tabular}


1. táblázat: (folyt.)

\begin{tabular}{|l|l|l|}
\hline Indikátor & Lengyel egyetemi tanács & Konzisztórium \\
\hline & $\begin{array}{l}\text { tagok nem lehetnek közszol- } \\
\text { gálatban foglalkoztatottak } \\
- \text { politikai befolyás elkerülendő }\end{array}$ & $\begin{array}{l}\text { részletes összeférhetetlenségi szabályok (közszol- } \\
\text { gálat, párt, önkormányzat, más intézmény vezetője, } \\
\text { konzisztóriumának vagy szenátusának tagja, saját } \\
\text { alkalmazott, hallgató) }\end{array}$ \\
\hline & nincs ilyen rendelkezés & díjazás nincs \\
\hline
\end{tabular}

* A rektor személyéről egy, az oktatók és hallgatók által választott elektori testület dönt, rektorjelöltet az egyetemi tanács mellett más is állíthat.

** Kevés egyetem, pl. a varsói döntött külső tagok mellett.

\section{A két board hatásköre}

A lengyel és a magyar állami felsőoktatási intézmények ${ }^{7}$ vezetési struktúrája csak részben mutat hasonlóságot. Előbbiek esetében a 2018-as reformot követően három szereplő osztozik az egyetemvezetési hatáskörökön: a rektor, a szenátus és az egyetemi tanács. Magyarországon az egyszemélyi vezető hatásköre eleve két első számú vezető, a rektor és a kancellár között oszlik meg és mellettük találjuk a szenátust és a konzisztóriumot. ${ }^{8}$ A lengyel felsőoktatás történetében az egyetemi tanács az első olyan egyetemvezetői testület, amelyben külső tagok is részt vesznek - Magyarországon ennek már lassan két évtizedes hagyománya van (vö. társadalmi tanács, irányító testület kísérlete, gazdasági tanács, konzisztórium). A két testület hatásköre között lényeges a különbség, mondhatni a hatásköri egyenes két végén helyezkednek el: a lengyel modell a véleményezést helyezi előtérbe, míg a magyar megoldásban az egyetértési jog révén a döntéshozatalban való közremüködés is meghatározó. Emellett az előbbi sokkal tisztább profilú testület, a konzisztórium esetében számos testületi hatáskörtípus keveredik.

A lengyel egyetemi tanács véleményezi az egyetemi stratégia és az alapszabály tervezetét, valamint felügyeli az egyetem gazdasági tevékenységét, a vezetést, ennek keretében véleményt nyilvánít a költségvetési tervezetekről, jóváhagyja a költségvetés végrehajtásáról szóló beszámolót, illetve az ellenőrzési jelentést. A klasszikus véleményező és ellenőrző funkciók mellett egyetlen sajátos jogköre, hogy - a szenátus véleményezése mellett - ő is javasolhat rektorjelöltet. (A rektor személyéről az oktatók és hallgatók által választott elektori testület dönt.) Az egyetemi szabályzatok további hatásköröket is megállapíthatnak számára.

A konzisztórium ehhez képest sokkal többféle jogosítvánnyal bír, amelyek között a társadalmi-gazdasági környezet becsatornázása már alig érhető tetten, a kormányzati érdekek érvényesítése annál inkább. Ezek típusa alapján keveredik, hogy konzultatív, ellenőrző vagy döntéshozó testületről van-e szó. Előbbi az intézmény stratégiai döntéseinek megalapozására, valamint a gazdálkodási tevékenység szakmai támogatására irányuló feladata, de hatáskörébe tartozik a gazdálkodási tevékenység ellenőrzése is. Ebben még

7 A magyar felsőoktatási intézmények esetében kizárólag az állami egyetemeket vizsgáltuk, mivel a nem állami intézményeknek 2019-re olyan nagy lett a szervezetalakítási szabadságuk, amely jelen terjedelmi korlátok között általános következtetések levonását nem teszi lehetővé. (Részletesebben lásd: Rónay 2020.)

8 Lásd a nemzeti felsőoktatásról szóló 2011. évi CCIV. törvényt és az azt módosító törvényeket: a kancellár jogintézményét bevezető 2014. évi XXXVI. törvényt, illetve a konzisztóriumot bevezető 2015. évi CXXXI. törvényt. 
hasonlít a lengyelhez, de a szenátusnak az intézményfejlesztési terv, annak részeként a kutatási-fejlesztési innovációs stratégia, a költségvetés és az éves beszámoló, valamint a vagyongazdálkodási terv elfogadása során, továbbá gazdálkodó szervezet alapítása, gazdálkodó szervezetben részesedés szerzése tárgyában meghozott határozatai érvényességéhez kötelező egyetértési joga révén döntéshozó funkciót is betölt (Rónay 2020).

\section{A board összetétele, megalakitása}

A lengyel törvény az egyetemek méretétől függően hét-vagy kilenctagú testület létrehozását írja elő. Bármely esetben a tagok felének külső tagnak kell lennie. A másik három vagy négy tag az intézményi szenátus döntésétől függően külső vagy belső személy. A konzisztórium esetében öttagú testületről van szó, amelynek három tagja csak külső személy lehet. A belső tag hivatalból a rektor és a kancellár. Persze a kancellár is csak annyiban számít belsőnek, hogy az intézmény munkajogi állományába tartozik, de a miniszterelnök kinevezési, illetve a miniszter utasításra is kiterjedő munkáltatói joga, valamint az egyetemek minimális közremüködése (a pályázati eljárásban a bizottságban a rektor részt vesz) a kiválasztás, megbízás során sokkal inkább külső szereplőként definiálja. És még az egyetlen belső tagnak számító rektor felett is fennáll a miniszter munkáltatói joga, tehát az utasítás munkajogi lehetősége. Míg a lengyel egyetemi tanács tagjai esetében az egyetlen megkötés a hallgatói önkormányzat elnökének hivatalbóli részvétele (tehát ő a hetedik vagy kilencedik tag), a konzisztórium müködésében a hallgatói önkormányzat nem vesz részt.

A másik lényeges különbség a tagság keletkezése. A lengyel egyetemi tanács minden választott tagjáról a szenátus dönt. Ugyancsak a szenátus hatásköre a visszahívás is. Ezzel szemben a három konzisztóriumi tag személyébe sem a szenátusnak, sem a hallgatói önkormányzatnak nincs érdemi beleszólása. Ugyan tehetnek javaslatot, de annak figyelembevétele kizárólag a miniszteren múlik. A javaslattételre jogosultak között még a felsőoktatási intézmény gazdasági-társadalmi környezetének meghatározó szerveit is megtaláljuk, de hogy ez pontosan mely szerveket jelenti, arra vonatkozóan már nincs információnk, és azt sem írja elő semmi, hogy ehhez a szférához tartozó személyt kell-e javasolniuk és e javaslatot figyelembe kell-e venni. A kiválasztási folyamat nem publikus, ugyan a végrehajtási rendelet előírja, hogy a javasolt és delegált tagok névsora, szakmai önéletrajza a minisztérium honlapján biztosítva nyilvános legyen, azonban ott ilyen adatra mutató link nem lelhető fel. A felsőoktatási intézmények zöménél sem találunk erre vonatkozó információt, több esetben az oldal jelszóval védett, amely egyébként összhangban áll a transzparenciát korlátozó azon jogszabályi rendelkezéssel, miszerint csak a konzisztórium által hozott határozatokat kell és azt is csak a felsőoktatási intézmény szabályzatának megfelelő módon nyilvánosságra hozni.

Tehát miközben a lengyel szabályozás kifejezetten rögzíti, hogy sem a kormány, sem a minisztérium nem rendelkezik felhatalmazással a tagok kinevezésére, illetve visszahívására, a magyar rendelkezések kifejezetten és alapvetően miniszteri hatáskörként határozzák meg azokat, amely összhangban áll a Koncepció és a Stratégia (2016) ama gondolatával, miszerint a konzisztórium a fenntartó állam (a kormány) érdekeit érvényesítő testület. Ez következik a konzisztóriumi tagok jogállásából is: a kancellár és egyértelmű szabály híján (mert se nem kormányzati tisztségviselők, se nem megbízási jogviszony keretében foglalkoztatottak) - a delegáltak esetében (igaz csak a delegálási 
jog tartalmából) sokkal inkább erre következtethetünk és nem a javaslattevők felé fennálló bármilyen kötelezettségre. A belső, ti. akadémiai érdekeket legfeljebb a rektor tudja megjeleníteni.

Abban mindkét nemzeti szabályozás hasonló, hogy szigorú összeférhetetlenségi szabályokat fogalmaz meg. Egyik szerint sem lehet tag olyan személy, aki a tág értelemben vett közigazgatásban (központi és helyi államizgatás, önkormányzati igazgatás) dolgozik. A lengyel szabályozás a közvetett politikai beavatkozás elkerülését fogalmazza meg kívánalomként, a magyar összeférhetetlennek nyilvánítja a párttisztséget és a képviselőséget is. Sőt a magyar még tágabb kört húz meg: további kizáró ok az intézménnyel fennálló vezetői, foglalkoztatotti vagy hallgatói jogviszony, illetve más intézmény vezetői, konzisztóriumi, szenátusi tagsággal járó tisztség is.

\section{Fogadtatás és értékelés}

Az egyetemi tanácsok bevezetését még a reform okait megértők között is csak kritika fogadta, akik azt hangsúlyozták, hogy annak a lengyel felsőoktatásban nincs hagyománya. Ez pedig a minták, jó gyakorlatok hiányát is jelentette, ami azért keltett aggodalmat, mert a lengyel esetre is releváns, szervezetekkel kapcsolatos tanulmányok (DiMaggiPowell 1983) szerint modellek hiányában az új modell bevezetése előtt álló szervezetek hajlamosak tradicionális, kulturális beágyazottsággal rendelkező szervezeti mintákat követni. Azaz félő volt, hogy nem lévén más, a lengyel állami vállalatok rendkívül átpolitizálódott és pártérdekek szolgálatában álló felügyelő bizottságai lesznek a minták. A sikeres külföldi mintákat (Ausztria, Finnország, Németország, Hollandia) azoknak a környezetüktől erősen hermetikusan elzárt lengyel felsőoktatástól jelentősen eltérő környezete miatt vetették el. Amint láthattuk, a magyar fogadtatás hasonló volt az irányító testületek, a gazdasági tanácsok, illetve a konzisztórium esetében is, noha a konzisztórium bevezetése - szemben Lengyelországgal - nem volt előzmény nélküli.

De Boer elemzése (2018) szerint az egyetemi vezetés megválasztásában való részvétel a felsőoktatásban az autonómia (és a hatalom) egyik legfontosabb szimbolikus eleme. Nem véletlen, hogy a legerősebb ellenállás mindkét országban a különféle testületek rektorválasztó hatásköre miatt volt: Lengyelországban 145 professzor írta alá az ezzel összefüggő követelést, és az akkor még ereje teljében lévő és alkotmányosan is támogatott magyar professzori kar reakciója ugyanez volt az irányító testület e jogköre, illetve erőtlenebbül a konzisztórium e hatásköre kapcsán. A konzervatív akadémiai szféra ugyanis az egyetemek piaci környezetbe kényszerítését (a magánszektorból származó laikus tagok révén) autonómiájukat a szabadpiac logikájának alárendelő neoliberális trendként értékeli.

$\mathrm{A} z$ akadémiai szféra lobbierejének és befolyásának jelentős eltérését mutatja, hogy a lengyel kormány eredeti koncepciója helyett végül egy hatalma legnagyobb részétől a hosszú és viharos jogalkotási folyamat során fokozatosan megfosztott, a hatalom valódi forrása helyett inkább szimbolikus változást jelentő testület valósult meg. Azaz a történelmi okok és az akadémiai közösség erős ellenállása képesek voltak meghiúsítani a külső tagok többségéből álló, az egyetemek pénzügyeinek felügyeletében széles hatáskört, a rektorok megválasztásában vagy kinevezésében erős (ha nem is döntő) szerepet betöltő testület bevezetését. A konzervatív lengyel egyetemi szféra elérte, hogy az érdemi reform kudarcba fulladt. 
Az ellenállás a konzisztóriummal szemben sem maradt el, azonban a lengyelhez képest jóval gyengébb volt, és sikertelensége különösen a 2005-ös kísérlet kisiklatásának tükrében feltűnő. Mindez azonban érthető, ha a reform előzményeit is figyelembe vesszük. A kormányzat folyamatos autonómiazsugorító intézkedéseivel szembeni állandó tiltakozás lényegében kifárasztotta az akadémiai szférát. Ráadásul - szemben Lengyelországgal - az autonómia már nem számít érinthetetlennek, az Alaptörvény nemcsak nem garantálja azt, de korlátozásának lehetőségét a kormány számára biztosítja. Mindazonáltal a szakirodalomban nem maradt el a konzisztórium kritikája. Volt, aki az intézményen belüli bizalom felszámolásaként értékelte (Fábri 2018), mások szerint a kialakított menedzsmentstruktúra egyáltalán nem korszerű és kizárólag az autonómia csökkentését szolgálja (Hegedüs-Polónyi 2015), egyre inkább a technostruktúrát erősítő gépi bürokráciát valósít meg (Keczer 2016). Felmerült, hogy a Koncepcióban korábban megígért társadalmi-gazdasági szféra képviseletének törvényi garanciája és gyakorlati megvalósulása hiányzik (Veres-Golovics 2016), sőt ehelyett valójában az autonómia felszámolása és a tradicionális akadémiai tevékenységek visszaszorítása felé tesz jelentős lépést (Craciun-Mibut 2017). Ezek a kritikák is jobbára a jogszabály elemzésére szorítkoznak, ugyanis szemben a lengyel egyetemi tanácsokkal, amelyek a lengyel törvényi követelményeknek eleget téve teljes mértékben transzparensen müködnek ideértve a tagokra vonatkozó, egészen a juttatásokra kiterjedő adatok nyilvánosságát, a konzisztóriumok müködését szinte teljes homály fedi (lásd részletesen: Rónay 2019a, 2019b).

A jelenlegi lengyel és a 2010 elötti magyar történetben közös vonás, hogy noha úgy tünik, a kormány elkötelezett (volt) az egyetemvezetés professzionalizációja és - föleg Lengyelországban - a stakeholderek bevonása mellett, az akadémiai szféra vagy nem (volt) hajlandó elfogadni új irányítási szabályokat vagy egyszerüen nem akarta megosztani az egyetemek feletti hatalmát. Különösen igaz volt ez a rektorok esetében, akik kifejezetten hatáskörük korlátozásának eszközeként értelmezték a reformot - legyen szó akár a lengyel egyetemi tanács, akár a magyar irányító testület vagy a gazdasági tanács bevezetéséröl. A lengyel egyetemi világ rejtett bizalmatlansággal viseltetik az akadémiai közösség belső ügyének tekintett egyetemi kormányzásban való bármiféle külső részvétellel szemben, így egy boardszerü testületre is az egyetemi müködésbe mélyen beágyazódott akadémiai identitásba való radikális beavatkozás szimbólumaként tekint; aminek ugyan előnye, hogy ezáltal a tudományos közösség eröteljes autonómiát élvez, ám úgy tűnik, hogy elsődlegesen ennek köszönhető a reformokkal szembeni állhatatos ellenállás is (Kwiek 2015; Antonowicz 2015; Dobbins 2015). Más kérdés, hogy az izoláció előbb-utóbb a külső forrásbővítés kárára mehet majd. Ennek ellenére félve, hogy a lengyel politikai tabu egyikét ledöntve megsérti az egyetemi autonómiát, a kormány visszakozott, nem akarta reformját az akadémiai közösség akaratával szemben kikényszeríteni. Magyarországon a helyzet hasonló lehetett volna, nem véletlen, hogy az alkotmányozó többség igen hamar az alapjogi garanciák felszámolásával kezdte meg a menedzsmentstruktúra reformját (Rónay 2018, 2020) megteremtve annak lehetőségét, hogy rákényszeríthesse akaratát az egyetemekre.

\section{Konklúziók}

A lengyel egyetemi tanács és a magyarországi konzisztórium létrehozásának módját és szabályaikat összehasonlítva láthatjuk, hogy a közös kulturális és politikai örökség 
ugyanazt a reakciót váltotta ki az akadémiai szférában. A demokratikus fordulatig mindkét ország több nagyhatalom elnyomásától szenvedett, így egyetemi oktatóiknak soha nem volt esélyük valódi akadémiai szabadság és autonómia megtapasztalására. A kommunista korszak előtt a szabadság és az autonómia csak látszólagos volt. Bár az egyetemi modellek sok elemükben hasonlítottak a klasszikus Humboldt-modellhez, az állami befolyás folyamatosan erős volt. A második világháború után a kommunista párt erősen kontrollálta a felsőoktatási intézményeket és az akadémiai tevékenységet. Egyetemi oktatók generációi nőttek fel, nap mint nap tapasztalva a szabadság és az autonómia hiányát, és szerencsésebb esetben személyes látogatás során a nyugati egyetemek sokkal jobb feltételeit. Nem meglepő, hogy a demokratikus fordulat után a szféra ragaszkodott a szabadsághoz és az autonómiához, és megpróbálta azokat a lehető legjobban megőrizni. Ezért az akadémiai szféra intenzív ellenállásához vezettek még a legésszerübb kezdeményezések is, ha azok képesek voltak megváltoztatni ezeket a körülményeket (Dobbins 2015). Ezért fordulhatott elő, hogy az akadémiai szférából csak kevesen ismerték fel a változások szükségességét, és támogatták a felsőoktatási intézmények vezetési struktúrájának korszerűsítését.

Végső soron leszögezhetjük, hogy a két testület bevezetése ugyanazt a reakciót eredményezte, miközben létrehozataluk oka és az intézményi autonómiához füződő kapcsolatuk és feladataik is nagyon különbözőek. Lengyelországban a kormány felismerte egyrészt, hogy az egyetemi szervezetek nagyon lazán kapcsolódtak egymáshoz (Weick 1976), vezetési készségekkel és erőforrásokkal nem rendelkező szervezeti egységek kvázi szövetségeként müködtek. Ebből arra a következtetésre jutott, hogy a szerteágazó szabályozás éppen, hogy lehetőségeiket korlátozó tényezőként funkcionál. Ezt a kormány a felsőoktatási intézmények számára biztosított nagyobb szervezeti autonómiával kívánta orvosolni, mivel a nagyobb autonómia az elszámoltathatóságot (felelősséget) is növeli (Bleikle 1998; Amaral-Meek-Larsen 2003; Maassen-Olsen 2007; Kretek-Dragšić-Kebm 2013). Az elszámoltathatóságot tágan, az egyetemek társadalmi elszámoltathatóságára kiterjesztve értelmezve a megoldás az egyetemi tanács létesítésében adódott, mivel a társadalmi-gazdasági környezettel való szoros kapcsolat, az érdekelt felek részvétele biztosíthatja ezt.

Eközben Magyarországon - bár a társadalmi-gazdasági kapcsolat szintén említésre került - a konzisztórium bevezetésének fó oka az autonómia korlátozása volt. A szakpolitikai dokumentumok világosan rögzítik, hogy az intézményi autonómia nem foglalja magában a nem akadémiai kérdéseket, ezért a kormánynak mint fenntartónak jogában áll közvetlenül ellenőrizni és befolyásolni azt akár a napi működés szintjén is.

A különböző megközelítések megjelennek a testületek választási folyamatában is. Míg Lengyelországban a szenátus hatásköre a tagok kiválasztása, és az egyetlen korlátozás a külső tagok minimális száma, amely nem éri el az összes tag számának felét sem, Magyarországon a tagok többségét a kormány választja ki és delegálja, sőt egy további tag (a kancellár) közvetlenül a kormányhoz tartozik (a kinevezési és a munkáltatói jog alapján). Mint láttuk, a lengyel törvény biztosítja a szenátus hatalmát az egyetemi tanács felett, ezáltal közelebb hozva a társadalmi-gazdasági környezetet és növelve az autonómiát, ami összhangban áll a kormány egyértelmű szándékával. Szemben Magyarországgal, ahol az autonómia apránként felszámolásra kerül. A számos eltérés ellenére az akadémiai szféra reakciója azonos: egyaránt rendkívül szkeptikus és erősen gyanakvó. 
- RÓNAY ZOLTÁN - DOMINIK ANTONOWICZ - MARTA JAWORSKA: LENGYEL ÉS MAGYAR VEZETŐ... - -

\section{IRODALOM}

Amaral, A., Meek, V. L. \& Larsen, I. M. (2003) The Higher Education Managerial Revolution? Dordrecht, Springer (Netherlands).

Antonowicz, D. (2015) Między siła globalnych procesów a lokalną tradycja. Polskie szkolnictwo wyższe $w$ dobie przemian [Between the Power of Global Processes and Local Tradition. Polish Higher Education in the Era of Changes]. Torun, Uniwersytetu Mikołaja Kopernika w Toruniu.

BARAKONYi K. (2004a) Egyetemek irányítása: a középkori egyetemtől a Bologna-folyamatig. Magyar Tudomány, Vol. 110. No. 4. pp. 513-526.

Barakony K. (2004b) Egyetemi kormányzás. Merre tart Európa? Közgazdasági Szemle, Vol. 51. No. 6. pp. 584-599.

Barakony K. (2009) Megtorpant intézményirányítási reform. Új pedagógiai Szemle, Vol. 59. No. 12. pp. 3-42.

Bergan, S. (2002) Institutional Autonomy between Myth and Responsibility. In: A. Barblan (ed.) Autonomy and Responsibility. The University's Obligations for the XXI. Century. Observatory Magna Charta Universitatum. Bologna, Bononia University Press. pp. 49-66.

Bleiklie, I. (1998) Justifying the Evaluative State: New Public Management Ideals in Higher Education. European Journal of Education, Vol. 33. No. 3. pp. 299-316.

Clark, B. R. (1998) Creating Entrepreneurial Universities: Organisational Pathways of Transformation. Oxford, Pergamon.

Craciun, D. \& Minut, G. (2017): Requiem for a Dream: Academic Freedom under Threat in Democracies. International Higher Education, Vol. 2017. No. 90. pp. 15-16.

De Boer, H. F. (2018) The Governance of Higher Education Systems and Institutions in Europe. Paper Presented at International Workshop "A Comparative Study of University Governance, Institutional Leaders and Leadership in East Asia and the Pacific" Hiroshima, Japan.

De Groof, J., Švec, J. \& Neave, G. (1998) Democracy and Governance in Higher Education. London, The Hague; Boston, Kluwer Law International.

DiMaggio, P. J. \& Powell, W. W. (1983) The Iron Cage Revisited: Institutional Isomorphism and Collective Rationality in Organizational Fields. American Sociological Review, Vol. 48. No. 2. pp. 147. https://doi.org/10.2307/2095101.

Dobbins, M. (2015) Exploring the Governance of Polish Public Higher Education: Balancing Restored Historical Legacies with Europeanization and Market Pressures. European Journal of Higher Education, Vol. 5. No. 1. pp. 18-33. https://doi.org/10.1080/21568235. 2014.969289.

Dobbins, M. \& Knill, C. (2009) Higher Education Policies in Central and Eastern Europe: Convergence toward a Common Model? Governance, Vol. 22. No. 3. pp. $397-$ 430.

Dziedziczak-Foltyn, A. (2018) Reformy w polskim szkolnictwie wyższym po 1990 r. w świetle nauki o polityce publicznej [Reforms in Polish Higher Education after 1990 in the Light of Public Policy Science]. Studia z Polityki Publicznej, Vol. 18. No. 2. pp. 9-23.

Fábri Gy. (2018) Bizalom a felsőoktatásban. Educatio, Vol. 27. No. 4. pp. 640-656.

Fried, J. (2006) Higher Education Governance in Europe: Autonomy, Ownership, and Accountability - A Review of the Literature. In: J. Kohler \& J. Huber (eds): Higher Education Governance between Democratic Culture, Academic Aspirations and Market Forces. Strasbourg, Council of Europe Publishing. pp. 79-133. 
Fulton, O., Santiago, P., Edquist, C., El-Khawas, E. \& Hackl, E. (2007) Thematic Review of Higher Education in Poland. OECD, Paris.

Hegedűs A. \& Polónyi I. (2015) Az egyetemvezetés hazai útvesztői. Köz-Gazdaság, Vol. 10. No. 2. pp. 67-86. http://unipub.lib.uni-corvinus.hu/2035/1/KG_2015n2p67. pdf [Letöltve: 2020. 01. 03.]

Нrubos I. (2006) A 21. század egyeteme. Educatio, Vol. 15. No. 4. pp. 665-683.

Hrubos I., Szentannai Á. \& Veroszta Zs. (2003) A gazdálkodási filozófia és gyakorlat érvényesülése az egyetemeken. Budapest, Oktatáskutató Intézet.

KeCZer G. (2007) A magyar egyetem-irányítás reformkísérlete 2002-2006. Jelenkori gazdasági és társadalmi folyamatok, Vol. 2. No. 1. pp. 27-37. (Szeged, SZTE MK.)

Keczer G. (2008) A gazdasági tanácsokkal kapcsolatos működési tapasztalatok az egyetemeken. Jelenkori gazdasági és társadalmi folyamatok, Vol. 3. No. 1. pp. 69-72. (Szeged, SZTE MK.)

Keczer G. (2016) Hatalmi viszonyok az egyetemeken - szervezettudományi megközelítésben. In: Szirmai É., Tóth Sz. \& UUjvári E. (eds) A hatalom jelei, képei és terei: egyetemi tankönyv. Szeged, Szegedi Egyetemi Kiadó, Juhász Gyula Felsőoktatási Kiadó. pp. 35-48.

Koncepció: Fokozatváltás a felsőoktatásban. A teljesítményelvű felsőoktatás fejlesztésének irányvonalai. https://www.kormany.hu/download/d/90/30000/ fels\%C5\%91oktat\%C3\%A1si\%20koncepci\%C3\%B3.pdf [Letöltve: 2019. 12. 30.]

Kretek, P. M., Dragšić, Ž. \& Kehm, B. M. (2013) Transformation of University Governance: On the Role of University Board Members. Higher Education, Vol. 65. No. 1. pp. 39-58. https://doi.org/10.1007/s10734-012-9580-x [Letöltve: 2020. 01. 23.]

Kwiek, M. (2015) The Unfading Power of Collegiality? University Governance in Poland in a European Comparative and Quantitative Perspective. International Journal of Educational Development, Vol. 43. pp. 77-89. https://doi.org/10.1016/ j.ijedudev.2015.05.002.

MaAssen, P. \& Olsen, J. P. (2007, eds) University Dynamics and European Integration. Dordrecht, Springer.

Polónyi I. (2006) Az egyetemvezetés lassú változása. Educatio, Vol. 15. No. 4. pp. 756773.

PolóNyi I. (2009) A hazai felsőoktatás gazdasági működése, szerveződése és vezetése a 2000-es évek legelején. Új Pedagógiai Szemle, Vol. 59. No. 8-9. pp. 3-26.

PopŁonkowski, T. (1996) Autonomia uczelni, instytucjonalne ograniczenia autonomii, kierunki zmian [University Autonomy, Institutional Limits of Autonomy, Directions of Changes]. In: M. DąBrowa-Szefler \& M. PAstwa (eds) Finansowanie i zarządzanie szkolnictwem wyższym Polska-Holandia [Financing and Managing Higher Education in Poland and the Netherlands]. Warszawa, UW. CBPNiSW. pp. 123-133.

PSF (2017) Peer Review Poland's Higher Education and Science System. https://rio. jrc.ec.europa.eu/sites/default/files/report/PSF-Peer_review_Poland__FINAL\%20 REPORT.pdf [Letöltve: 2020. 01. 06.]

RónAy Z. (2018) Centralizations and Autonomies: The Delimitation of Education by the Hungarian Government. In: N. Popov, Ch. Wolhuter, J. M. Smith, G. Hilton, J. Ogunleye, E. Achinewhu-Nworgu \& E. Niemczy (eds) Education in Modern Society BCES Conference Books, Volume 16. Sofia, Bulgarian Comparative Education Society (BCES). pp. 177-182. 
- RÓNAY ZOLTÁN - DOMINIK ANTONOWICZ - MARTA JAWORSKA: LENGYEL ÉS MAGYAR VEZETŐ... - -

Rónay Z. (2019a) Consistory - the Obscure Subject of State Control. In: Kováts G. \& Rónay Z. (eds): In Search of Excellence in Higher Education. Budapest, Corvinus University of Budapest Digital Press. pp. 71-87.

RónAY Z. (2019b) A konzisztórium helye, szerepe, működésének célja az állami felsőoktatási intézmények irányításában és vezetésében - kérdések és válaszkísérletek. In: JuHÁsz E. \& Endrődy O. (eds) Oktatás-Gazdaság-Társadalom. Budapest, Debrecen, Debreceni Egyetem, Magyar Nevelés- és Oktatáskutatók Egyesülete (HERA). pp. 752-765.

RónAY Z. (2020) Vezetők, testületek, felelösség a felsőoktatási intézményekben. Budapest, L'Harmattan.

Setényi J. (1994) Felsőoktatás-politika. Educatio, Vol. 3. No. 1. pp. 36-49.

Stratégia (2016) Fokozatváltás a felsőoktatásban - középtávú szakpolitikai stratégia 2016. https://www.kormany.hu/download/c/9c/e0000/Fokozatvaltas_Felsooktatasban_ HONLAPRA.PDF [Letöltve: 2019. 12.30.]

Szolár É. (2010) A felsőoktatás reformja és a Bologna-folyamat Magyarországon. Magyar Pedagógia, Vol. 110. No. 3. pp. 239-263.

Thомas, E. (2002) The Role of University in Modern Society. The Bristol Society meeting, 25. Sept. 2002. (Cited by Barakonyi 2004b.)

Veiga, A., Magalhães, A. \& Amaral, A. (2015) From Collegial Governance to Boardism: Reconfiguring Governance in Higher Education. In: J. Huisman, H. De Boer, D. D. Dill \& M. Souto-Otero (eds) The Palgrave International Handbook of Higher Education Policy and Governance. London, Palgrave Macmillan. pp. 398-416.

Veres P. \& Golovics J. (2016) Új szereplők a magyar felsőoktatásban: Kancellári rendszer és konzisztórium. In: Kováts G. (ed.): A kancellári rendszer bevezetése a magyar felsöoktatásban. Tapasztalatok és várakozások. Budapest, Budapesti Corvinus Egyetem, Nemzetközi Felsöoktatási Kutatások Központja. pp. 7-22.

Vilalta, J. (2003) Higher Education Governance Trends - A Comparative Analysis of Five European Countries. EAIR Annual Forum. Limerick. (Cited by Barakonyi 2004b.)

Weick, K. E. (1976) Educational Organizations as Loosely Coupled Systems. Administrative Science Quarterly, Vol. 21. No. 1. pp. 1-19. https://doi.org/ $10.2307 / 2391875$

World Bank/EIB (2004) Tertiary Education in Poland/Szkolnictwo wyższe w Polsce. World Bank, Washington.

A cikk a Creative Commons Attribution 4.0 International License (https://creativecommons.org/licenses/ by/4.0/) feltételei szerint publikált Open Access közlemény, melynek szellemében a cikk bármilyen médiumban szabadon felhasználható, megosztható és újraközölhető, feltéve, hogy az eredeti szerző és a közlés helye, illetve a CC License linkje és az esetlegesen végrehajtott módosítások feltüntetésre kerülnek. (SID_1) 